\title{
Relationship between Adolescent Students' Motivation in Re- spect to the Use of Tablets in the Classroom and Sustainable Development Goals 4, 5 and 9
}

\author{
David Mendez ${ }^{*}$, Miriam Mendez ${ }^{2}$ and Juana Maria Anguita ${ }^{3}$ \\ 1 University Alfonso X el Sabio, Villanueva de la Canada, Spain; dmendcoc@uax.es \\ 2 University Alfonso X el Sabio, mmendcoc@uax.es \\ 3 University Alfonso X el Sabio, janguace@uax.es \\ * Correspondence: dmendcoc@uax.es.
}

\begin{abstract}
The Sustainable Development Goals (SDGs) 4, 5 and 9 are related to the quality of education, gender equality and the use of new technologies. It is important to bear in mind that a major part of the success of education has to do with students' motivation, which is closely connected to the use of technologies in the classroom. For this reason, a study was carried out with 131 students aged 12 and 13, 58 girls and 73 boys, who use a tablet in their Science classes. The purpose of the study was to determine, based on the Self Determination Theory, the level of intrinsic motivation of those adolescents towards the use of tablets in the classroom. The study measured the interest they have in the tasks and the value they assign to said tasks, as well as their perception of their competence in using tablets. The results reveal that students' motivation is high without significant differences between girls and boys when technological resources are included in teaching-learning processes. This is reflected by the improvement of their academic performance. It is thus possible to state that SDGs 4,5 and 9 can be achieved.
\end{abstract}

Keywords: Sustainable Development Goals; Self-Determination Theory; motivation; tablet; gender

\section{Introduction}

\subsection{Sustainable Development Goals and their Relationship to Education}

In 1990 the World Declaration on Education for All and Framework for Action to Meet Basic Learning Needs set the basis for reconsidering education at a global level, establishing a calendar geared at adopting measures and monitoring the actions implemented [1].

Subsequently, two different but interconnected plans were drafted under the motto "Education For All", namely the Millennium Development Goals [2] and the Sustainable Development Goals [3]. The latter were an extension of the first plan, in which access to primary education together with equality of men and women were two major priorities.

Note should be made that in view of the impossibility of achieving the Millennium Development Goals by 2015, the Sustainable Development Goals (hereinafter referred to as SDGs) were proposed to give continuity to the former and adapt to the reality of the current context, covering 17 different areas and extending the deadline by which to achieve them to 2030. The objectives are organised by economic, social and environmental dimension or category, ensuring at all times compliance with human rights, gender equality and the reduction of inequalities [4].

Education is a major element of the 2030 Agenda, in which it has been assigned a strategic role as an independent area: SDG 4, Quality Education [5]. For this purpose, the objective focuses on inclusive and equitable education, and on promoting learning opportunities for everyone during their lifetime. The major SDG 4 objectives include not only the Millennium Development Goals in respect to education (to ensure primary education 
for all boys and girls [2], but also to ensure that all boys and girls successfully finish secondary education and thus facilitate an equitable access to higher education [6]. In consequence, SDG 5 on Gender Equality is particularly important, not only at the social level but also in an educational context. In other words, establishing synergies between SDG 4 and SDG 5 is both possible and necessary [7].

In addition to the clear relationship that exists between SDG 4 and SDG 5 in the current social context, they are also closely connected to SDG 9 on Industry, Innovation and Infrastructure. This objective highlights the role of the new technologies at present, and thus proposes significantly increasing access to Information and Communication Technologies (hereinafter referred to as ICTs) [2,6]. In fact, had it not been for the scope of said technologies during the COVID19 pandemic, it would have been very difficult to continue the schooling and training processes underway when the coronavirus appeared and currently in progress [8].

In this globalized 21st century world, ITCs form part of everyone's life. In fact, the majority of present day children and adolescents do not know any other reality in which they did not exist. For this reason, as ICTs are increasingly present, not only to optimize teaching-learning processes, but also for teaching obligatory content and to try to attain the aforementioned sustainable development objectives (SDGs 4, 5 and 9), it is necessary that school children feel motivated by learning provided by means of elements which attract them most, namely ICTs $[9,10]$.

From the foregoing it follows that in order to promote and provide sustainable education, it is necessary to have quality education (SDG 4) that avoids discrimination (SDG 5) and that facilitates access to Information and Communication Technologies (SDG 9). This quality education is closely related to students' motivation [11], which is usually considerable and is enhanced when ICTs are integrated in teaching-learning processes [12]. In this respect, note should be made of the Eurydice report in 2002, which highlights that quality education must foment the development of a series of key competences that enable individuals in general and children and adolescents in particular to grow and thrive throughout society, one of these key competences being the effective command and use of technology.

\subsection{Motivation: Self-Determination Theory}

The Self-Determination Theory developed by Ryan and Deci [13] focuses on the individuals' healthy development and on the accomplishment of their psychological needs. Therefore, learning has a relationship with cognitive and motivational aspects [14]. Grant and Dweck [15] argued that achievement goals are related to motivation of achievement, and that learning goals affect positively intrinsic motivation and performance when individuals face challenges, such as learning. McInerney, Marsh and Yeung [16] affirmed that goals help a person achieve desired results. Pintrich and De Groot [17] suggested that it is possible to study motivation according to three dimensions: competence perceived, value regarding the importance attributed to the task, and the emotional reactions produced.

Schunk [18] defined a goal as a standard of demand whereby individuals judge their success or failure. There were two types of goals: performance goals were related to validating one's capability, and learning goals focused on making an effort to learn and have command. The performance goal approach focuses above all on the "me", whereas the learning objectives or mastery approach focuses on the learning activity $[15,19,20]$.

Learning or mastery goals were positively associated with intrinsic motivation and academic performance, for instance self-efficacy, positive emotions and general well-being [21].

At present, when talking of motivation there are different theories shared by everyone [22,23], but there are several aspects connected to the Self-Determination Theory, being the achievement objectives the main ones:

- The expectation of achievement goals is related with competence [24]. 
- $\quad$ Personal motivation is determined by personal feelings and interests (intrinsic motivation), or by the influence of societal aspects aiming at getting a reward or avoiding a punishment (extrinsic motivation) [25].

- Following Bandura's theory of social-cognitive learning [26], competence perceived, also known as self-efficacy, has an influence on learning motivation according to what individuals think they have achieved and taking into account their previous experiences.

As stated by Dweck and Legget [27] in their causal attribution theories, the environment conditions human behaviour and, therefore, it can modify personality traits in a positive or negative way depending on personal expectations.

Nowadays, educators consider intrinsic motivation is a key aspect in the teaching and learning processes and their further achievements where parents also have a major role [28].

When individuals enjoy or feel any kind of pleasure while carrying out an activity without any outside influence, intrinsic motivation comes into play [29]. As far as it has already been explained, motivation can be intrinsic or extrinsic. In the particular case of extrinsic motivation a classification can be established depending on whether it is regulated internally or externally. In consequence, motivation may affect student's performance [30]. Within the educational context, there is usually a direct relationship between students' intrinsic motivation improvement and their active participation in the learning process [31].

There are three basic innate psychological needs according to the Self-Determination Theory [29]; namely, the need of competence, or achievement; need for autonomy, or the freedom of choice; and the need to be part of a group. Individuals' motivation and wellbeing raise when these needs are fulfilled. The freedom a person has to act and to make a choice (self-determination process) is associated to his/her intrinsic motivation. Intrinsic motivation is not linked to any kind of need. Human beings, with no exception, have an inborn predisposition to grow and develop [31, 32]. In order to feel motivated, support is always required to prevent any undermining [29].

The lack of freedom to act (extrinsic motivation) makes intrinsic motivation decrease $[29,33]$. That is to say, when individuals feel that others control their actions or decisions, they lose interest. For example, in the educational environment, exams, close-dates, or demanding educators, among others, can affect intrinsic motivation. On the other hand, the perceived competence of individuals when something has been successfully implemented without pressure makes intrinsic motivation rise. In the classroom teachers who support students' autonomy and critical thinking also contribute to enhance the aforementioned type of motivation.

As for personal and social relations (third type of innate human needs), it has to be highlighted that they reinforce individuals' motivation and wellbeing. Feeling cared, and safe are essential for human beings [34].

The Intrinsic Motivation Inventory (IMI) [35] assesses all these aspects in a test taking into account different factors and contexts related to self-regulation and intrinsic motivation.

\subsection{Effects of Technology on Education}

ICTs have become the engine of growth of the world economy. They also have an impact on the sustainability policies [36]. The OECD [37] fosters the use of these technologies at schools in order to prepare young people for adult life. In consequence, educational policies have reflected this particular situation. At the present time, there is growing tendency among teachers and schools incorporating technology to consider it is very useful to learn and motivate students [38]. In fact, the use of ICT gives the students more control over their educational experience and it encourages them to learn [39]. For this reason, not only the infrastructure in schools should increase but also the knowledge and competences in the use of technological resources amongst teachers. In doing so, teachers 
are qualified to use them well and effectively in the subject they teach and in managing their classrooms [38], thus meeting the objectives of SDGs 4 and 9 on Quality Education, and Industry, Innovation and Infrastructure, respectively [6].

Due to the positive influence of the use of technologies on the motivation towards learning, several studies have focused on studying the possible factors that have an impact on the use of technologies, one of which is gender. Research studies offer results of the possible differences that may exist in the motivation regarding the use of technologies between girls and boys [40-42], due to the differences in how they use the technologies or their previous experiences with them [43]. These studies report that there are differences in motivation towards the use of technologies between men and women, highlighting a more positive attitude in men than in women. However these differences are not found when it comes to using them for educational purposes [41, 44]. This shows that the education provided in industrialized countries is egalitarian and does not establish gender differences, an aspect which is fomented by the United Nations [3,6] in its SDG 5.

The meta-analysis conducted by Kay [45] confirms that there are few differences between the attitudes, the skills and the use of technology between boys and girls, although this is not the case in respect to the training received. He detects a small difference in the better attitude of boys towards the use of technologies as compared to girls, and differences in skills to use technology in higher education in favor of boys. The meta-analysis on the influence of gender on attitudes and motivation towards the use of technologies developed by Cai, Fan and Du [46] confirm a decrease of gender differences in the dimension of Affect and the dimension of Self-efficacy, but not in the dimension of belief.

Technological resources take part of students' routines and, at the same time, they offer different forms of communication compared to traditional ones enabling the development of diverse capacities [47]. Nevertheless, in certain occasions the use of ICT does not achieve all these objectives due to poor teacher training [48,49]. The potential of technology, its accessibility and students' interest on it make teachers feel appealed to use this type of resources [50].

Nowadays, most teachers are conscious of the different possibilities technology offers. To this respect and in relation to education, it helps implement active learning methodologies [51-53]. It should be highlighted that many students get distracted when mobile technology (namely tablets, laptops and cell phones) is used in class. These resources have contributed to the development of M-learning as an innovative methodology.

Although research is controversial concerning this new type of learning, in general, two perspectives can be distinguished. On the one hand, learning is approached from technology. And, on the other, learning takes into account individuals, and the scenarios and situations where education happens. In this setting, communication is a cornerstone since students feel the need to interact all the time. Therefore, conversing through mobile technology becomes an additional educational methodology $[55,56]$. Consequently, modern learning comprises cognitive aspects and the mastering of technology since a good command of the latter contributes to the development of creativity, the implementation of cooperative activities and inquire-based learning, and the strengthening of self-confidence $[57,58]$.

\section{Materials and Methods}

This research is aimed at comparing if there is any difference in the motivation of students (boys and girls) aged 12-13 when they use tablets or not in class. Three dimentions are taken into account: interest and satisfaction related to task performance, perceived competence and the importance given to tasks.

The instrument used to assess intrinsic motivation is based on the Intrinsic Motivation Inventory (IMI). It comprised 17 questions whose answers were applied a Likert scale with 5 different options. Two groups of students using tablets to complete science activities were administered the 17-question test. There were no significant differences in the sociocultural contexts and schools of students. 
The sample comprised 131 students, 58 girls and 73 boys, aged 12-13 at 1st year of Compulsory Secondary Education [ESO by the Spanish acronym]. The test was administered during a class in the month of December of the 2017-2018 school year, right before Christmas holidays. The students had been using tablets at school for three years and for the entire school year up to the time of the test, which lasted 30 minutes and was completed online.

\subsection{Instrument}

The intrinsic motivation test given to the students consisted of 17 questions with a Likert scale. The students had to select from 1 to 5 as an answer for each item, 1 being equivalent to Nothing and 5 to A lot.

This instrument assessed the following dimensions: the subject's satisfaction or interest for a specific activity, his/her perception of the competence he/she has and the value or utility provided by the activity in which the subject is participating. All of these dimensions are closely related with the three innate psychological needs assigned to human beings by the Self-Determination Theory. Six items referred to the student's interest or satisfaction for the task he/she is performing, six to how competent the student considers himself/herself to be in using the textbook or the tablet, and five asking about the utility or the value they assign to the tasks they perform.

\section{Results}

The average and the standard deviations calculated from students' responses are shown below. Interest and satisfaction items results appear in Table 1.

Table 1. Average of students' answers to questions regarding their interest and satisfaction in connection with the tasks they perform.

\begin{tabular}{|c|c|c|}
\hline Item & Girls & Boys \\
\hline $\begin{array}{l}\text { I enjoy working at school } \\
\text { and at home }\end{array}$ & $4.03 \pm 1.20$ & $4.18 \pm 0.80$ \\
\hline $\begin{array}{l}\text { I have a good time working } \\
\text { at school and at home }\end{array}$ & $3.87 \pm 1.12$ & $4.09 \pm 0.62$ \\
\hline $\begin{array}{l}\text { After having worked on } \\
\text { school tasks, I feel better }\end{array}$ & $3.33 \pm 1.22$ & $3.78 \pm 1.06$ \\
\hline $\begin{array}{l}\text { I really wanted to use my } \\
\text { tablet to do my school tasks }\end{array}$ & $3.77 \pm 1.11$ & $4.03 \pm 1.07$ \\
\hline $\begin{array}{l}\text { I have enjoyed when the } \\
\text { teacher has explained us how } \\
\text { to work in class }\end{array}$ & $3.60 \pm 1.33$ & $3.86 \pm 0.96$ \\
\hline $\begin{array}{l}\text { I use my tablet to learn } \\
\text { things that are different from } \\
\text { what I learn at school }\end{array}$ & $3.70 \pm 1.39$ & $3.68 \pm 1.11$ \\
\hline
\end{tabular}

Boys express greater interest and satisfaction in five of the six questions. Girls only obtain a slightly higher result, namely 3.70 compared to 3.68 , for the item that refers to learning things that are different from what they learn at school. The most significant difference, namely 0.45 points, is for the question about how they feel when they do their work. The average in these questions for the girls is 3.72 and for the boys is 3.94; therefore the use of tablets has a very good effect on interest.

In Table 2 it is possible to see information related to the perceived competence of students using the textbook or the tablet as resources when they study.

Table 2. Average of students' answers to questions regarding how they perceive their competence to use the necessary tools to study. 


\begin{tabular}{lcc}
\hline \multicolumn{1}{c}{ Item } & Girls & Boys \\
\hline $\begin{array}{l}\text { I think I am good in tasks } \\
\text { done with the tablet at school }\end{array}$ & $3.73 \pm 1.29$ & $3.62 \pm 0.81$ \\
$\begin{array}{l}\text { I am satisfied with the work I } \\
\text { do with the help of the tablet } \\
\text { I think that I use the tablet } \\
\text { better than my classmates } \\
\text { I think that I understand } \\
\text { very well how I have to work } \\
\quad \text { at school and at home }\end{array}$ & $3.50 \pm 1.41$ & $4.47 \pm 0.67$ \\
$\begin{array}{l}\text { I like the way I was taught to } \\
\text { use the tablet to do my } \\
\text { school work }\end{array}$ & $3.37 \pm 1.44$ & $2.73 \pm 1.09$ \\
$\begin{array}{l}\text { I see my work as something } \\
\text { that I want to do and not as } \\
\text { an obligation }\end{array}$ & $3.50 \pm 1.23$ & $4.10 \pm 0.84$ \\
\hline
\end{tabular}

Both consider themselves competent when using the electronic device to do their school work, and the boys' results are better than girls in four questions. Girls get a better punctuation in two questions: it is slightly better in "I think I am good in tasks done with the tablet at school", 3.73 compared to 3.62, and a great difference (0.64) in the item "I think that I use the tablet better than my classmates", 3.37 compared to 2.73 . Boys achieve much better results in four questions, with an average difference of 0.72 . The greatest difference is 0.97 in the item "I am satisfied with the work I do with the help of the tablet". The average in this dimension is 3.45 for girls and 3.81 for boys.

The results in the dimension regarding the value of the tasks are shown in Table 3.

Table 3. Average of students' answers to questions regarding the value of the tasks they perform.

\begin{tabular}{|c|c|c|}
\hline Item & Girls & Boys \\
\hline $\begin{array}{l}\text { I think it's important to use } \\
\text { the tablet for school work }\end{array}$ & $4.20 \pm 0.91$ & $3.65 \pm 1.00$ \\
\hline $\begin{array}{l}\text { I think that learning at school } \\
\text { with the tablet is something } \\
\text { good for me }\end{array}$ & $3.96 \pm 1.23$ & $3.86 \pm 0.81$ \\
\hline $\begin{array}{l}\text { I think about working with } \\
\text { the tablet both at school and } \\
\text { at home }\end{array}$ & $3.93 \pm 1.00$ & $3.56 \pm 0.93$ \\
\hline $\begin{array}{c}\text { I think that using the tablet at } \\
\text { school has been of great } \\
\text { value for me }\end{array}$ & $4.30 \pm 0.86$ & $3.79 \pm 0.95$ \\
\hline $\begin{array}{l}\text { I feel like working more } \\
\text { when I use the tablet }\end{array}$ & $3.90 \pm 1.30$ & $3.62 \pm 1.18$ \\
\hline
\end{tabular}

Both consider that working with a tablet has been of great value for them, and that when they use this electronic device they feel like working more. In this dimension girls working with tablets have higher scores on all items. The smallest difference between girls and boys $(0.10)$ is in respect to students' consideration of learning at school with the tablet is something good for them. The biggest difference (0.55) is that the use of tablet is important for school work at school. In this case, the girls' average is 4.06 and the boys' is 3.70 . 
Both groups have very good results in these dimensions. Boys get better results than girls in 9 items and girls obtain better results in 8 items. The average of the 17 questions is 3.72 for girls and 3.82 for boys.

\section{Discussion}

There is no doubt concerning the benefits new technologies, in general, and tablets, in particular, have in the teaching and learning processes nowadays [59]. This is supported by the scores obtained in this research (3.72 and 3.82) in relation to the motivation students feel after using tablets at the high school to study and learn science.

Previous research, such as Sanz's [59], show that 91\% of students agree with the importance of using tablets in academic settings because they feel more motivated to study. Among these students, $47 \%$ of them think that the information presented with tablets is clearer.

This is confirmed by the study's results, since in the aforementioned sample students with tablets express a great motivation in all items. Boys have only one question below 3.5, namely "I think I use the tablet better than my classmates", and therefore it is only a matter of comparison with other students who use tablets. Girls have only three items with a punctuation below 3.5 but over 3, namely "I see my work as something that I want to do and not as an obligation", "After having worked on school tasks, I feel better" and the same item as the boys'.

It is possible to compare our results with other similar studies in Table 4, including one with 11 year old students who use textbooks and tablets [60] and another one with 14 year old students who use textbooks and tablets [61].

Table 4. Average of students' answers to questions regarding the value of the tasks they perform.

\section{Dimension}

11 year-old textbook

11 year-old tablet

14 year-old textbook

14 year-old tablet

12-13 year-old girls tablet

12-13 year-old boys tablet
Interest

Perceived competence

3.58

Value of the tasks

\subsection{7}

As shown in the table, the results of the sample show a great motivation for boys and girls. These results (use of tablet) are much better than those of 14 year-olds who use textbooks.

When the comparison is between students of different ages who use tablets, the differences are quite small. The youngest students seem to be more motivated and the oldest students seem to be less motivated than those younger students who use tablets. 
An idea that was not directly considered in the test was the use of the tool as support for cooperative work. Sanz [59] pointed out that $74 \%$ of students believed that the tablet had a clear cooperative use, and that it promoted said use.

A study conducted in Turkey in the framework of the FATIH Project to analyze, among 20614 and 15 year-old students in the 2011-2012 academic year, attitudes that could affect the use of tablets in the classroom found a positive attitude towards the use of technology and no significant differences between boys and girls [62].

\section{Conclusions}

According to the data obtained, students who use tablets are very motivated and, in general, they are more motivated than those who use textbooks. If motivation is associated to a better acquisition of the content to be learned, it can be inferred that the use of technology in the classroom can contribute to promoting quality education. This was found to be the case in the study carried out by Huertas and Pantoja [63], which provided evidence on how the use of ICTs in classrooms increased students' motivation, and how this is connected to a significant increase of their academic performance. Hence, this is a case in which the SDG 4 objective is met. Furthermore, by promoting the constructive use of ICTs in the classroom for learning purposes, SDG 9 is also fulfilled.

SDG 5 regarding gender equality is also achieved, since the differences between girls and boys are not significant, showing that the education received is equitable and that the minor differences obtained are connected to personal perceptions.

More specifically and taking into account one of the dimensions tested, boys who use tablets achieve better results in two dimensions and girls obtain a better score in the value of the tasks they have to perform.

When comparing the grading of interest and satisfaction shown by boys and girls in the performance of tasks, girls just obtained better marks in one out of the six questions, being all deviations larger in girls. The total difference in this first dimension (interest and satisfaction) between boys and girls is 0.22 .

The difference is greater when students are asked about how they perceive their competence when using the work tools. In this case, boys using tablets have higher scores for four questions; girls achieve better results in two items. The difference in this dimension is 0.36 .

In the third dimension, girls consider the tasks performed and the use of the electronic device to be more useful in comparison with boys in the six items. The difference is 0.36 .

In general terms, the incorporation of ICTs to the classroom has positive effects for the education of students, both girls and boys, at early stages of adolescence (12-13 years old) in respect to motivation.

Author Contributions: Conceptualization, J.M.A.; methodology, D.M.; formal analysis, M.M.; investigation, D.M., M.M. and J.M.A.; writing - original draft preparation, D.M. and M.M.; writingreview and editing, J.M.A. All authors have read and agreed to the published version of the manuscript.

Funding: This research was funded by Fundacion Universidad Alfonso X el Sabio and Santander Bank.

Data Availability Statement: The survey data presented in this study are available on request from the corresponding author.

Conflicts of Interest: The authors declare no conflict of interest. The funders had no role in the design of the study; in the collection, analyses, or interpretation of data; in the writing of the manuscript, or in the decision to publish the results. 


\section{References}

1. UNESCO, World Declaration on Education for All and Framework for Action to Meet Basic Learning Needs; UNESCO: New York, United States, 1990. Retrieved from https://unesdoc.unesco.org/ark:/48223/pf0000127583.

2. United Nations, United Nations Millennium Declaration, 2000. Retrieved from https://www.un.org/millenniumgoals/

3. United Nations, Sustainable Development Goals, 2015. Retrieved from https://www.un.org/sustainabledevelopment/

4. Gómez, C., Objetivos de desarrollo sostenible (ODS): una revisión crítica. Papeles de relaciones ecosociales y cambio global 2017/2018, 140, 107-118.

5. Calafell, G.; Banqué, N.; Grau, Q., Análisis del modelo didáctico de educación ambiental "La idea vector y sus esferas” desde el enfoque de los objetivos de desarrollo sostenible. Un caso: la Escuela del Consumo de Cataluña, Revista de Educación Ambiental y Sostenibilidad, 2019, 1, 1, 1302-1-1302-21.

6. United Nations, Transforming Our World: The 2030 Agenda for Sustainable Development, 2015. Retrieved from https://sdgs.un.org/publications/transforming-our-world-2030-agenda-sustainable-development-17981

7. Aragonés-González, M.; Rosser-Limiñana, A.; Gil-González, D., Coeducation and gender equality in education systems: A scoping review, Children and Youth Services Review, 2020, 111 [online]. DOI: https://doi.org/10.1016/j.childyouth.2020.104837

8. Cifuentes-Faura, J., Docencia online y Covid-19: la necesidad de reinventarse, Revista De Estilos De Aprendizaje, 2020, 13, 115127. Retrieved from http://revistaestilosdeaprendizaje.com/article/view/2149

9. Anguita, J. M.; Mendez, M.; Mendez, D., Motivación de alumnos de Educación Secundaria y Bachillerato hacia el uso de recursos digitales durante la crisis del Covid-19, Revista De Estilos De Aprendizaje, 2020, 13, 68-81. Retrieved from http://revistaestilosdeaprendizaje.com/article/view/2242

10. Jaudenes, A.; Mendez, D., La influencia del uso del tablet en la motivación en ciencias de los alumnos de secundaria, educación y futuro, 2019, 40, 93-107.

11. Bello, I.; Steffen, J.; Hayashi, K., Cognitive motivational systems and life satisfaction in serious and persistent mental illness, Quality of Life Research, 2011, 20, 7, 1061.

12. Passey, D.; Rogers, C.; Machell, J.; McHugh, G.; Allaway, D., The Motivational Effect of ICT on Pupils, Department for Education and Skills: London, 2003.

13. Deci, E. L.; Ryan, R. M., Self-Determination Theory and the Facilitation of Intrinsic Motivation, Social Development, and WellBeing, American Psychologist, 2000, 55, 1, 68-78.

14. Valle, A.; González, R.; Barca, A.; Núñez, J.C., Una perspectiva cognitivo-motivacional sobre el aprendizaje escolar, Revista de Educación, 1996, 311, 159-182.

15. Grant, H.; Dweck, C. S., Clarifying achievement goals and their impact, Journal of personality and social psychology, 2003, 85, 3, 541.

16. McInerney, D. M.; Marsh, H. W.; Yeung, A. S., Toward a hierarchical goal theory model of school motivation, Journal of Applied Measurement, 2003, 4, 335-357.

17. Pintrich, P. R.; De Groot, A., Motivational and self-regulated learning components of classroom academic performance, Journal of Educational Psychology, 1990, 82, 33-40.

18. Schunk, D. H., Self-efficacy for reading and writing: Influence of modelling, goal setting, and self-evaluation, Reading and Writing Quarterly, 2003, 19, 159-172.

19. Maehr, M. L.; Meyer, H. A., Understanding Motivation and Schooling: Where We' ve Been, Where We Are and Where We Need to Go, Educational Psychology Review, 1997, 9, 4, 371-409.

20. Maehr, M. L., Goal theory is not dead - Not yet anyway: A reflection on the special issue, Educational Psychology Review, 2001, 13, 177-185.

21. Kaplan, A.; Maehr, M. L., The contributions and prospects of goal orientation theory, Educational Psychology Review, 2007, 19, 141-184.

22. Manassero, A. M.; Vázquez, A., Validación de una escala de motivación de logro, Psicothema, 1998, 10, 2, 333-351.

23. Manassero, A. M.;Vázquez, A., Análisis empírico de dos escalas de motivación escolar, Revista electrónica de motivación y emoción, 2000, 3, 5-6.

24. Atkinson, J. W., An introduction to motivation, Van Nostrand: Princeton, United States, 1964.

25. Maehr, M. L.; Braskamp, L. A., The motivation factor: A theory of personal investment, Lexington Books/D. C. Heath and Com.: Lexington, MA, England, 1986.

26. Bandura, A., From thought to action: Mechanisms of personal agency, New Zealand Journal of. Psychology, 1986, $15,1-17$.

27. Dweck, C. S.; Leggett, E. L., A social-cognitive approach to motivation and personality, Psychological Review, 1988, 95, 2, 256273. doi:10.1037/0033-295X.95.2.256.

28. Ryan, R. M.; Stiller, J., The social contexts of internalization: Parent and teacher influences on autonomy, motivation and learning. In Advances in motivation and achievement; Pintrich, P.R., Maehr, M. L., Eds.; JAI Press: Greenwich, CT, England, 1991; Volume 7, pp. 115-149.

29. Ryan, R. M.; Deci, E. L., Intrinsic and extrinsic motivations: Classic definitions and new directions, Contemporary educational psychology, 2000, 25, 1, 54-67. 
30. Gottfried, A. E., Academic intrinsic motivation in elementary and junior high school students, Journal of Educational Psychology, 1985, 77, 6, 631-645.

31. Pintrich, P. R.; Schunk, D. H., Motivación en contextos educativos. Teoría, investigación y aplicaciones, Pearson: Madrid, 2006.

32. Deci, E. L.; Vallerand, R. J.; Pelletier, L. G.; Ryan, R. M., Motivation and Education: The Self-Determination Perspective, Educational Psychologist, 2011, 26, 3-4, 325-346.

33. Deci, E. L.; Ryan, R. M., 1991 A motivational approach to self: Integration in personality. In Nebraska Symposium on Motivation: Perspectives on motivation, Dienstbier, R. Ed.; University of Nebraska Press: Lincoln, United States; Volume 38, pp. 237-288.

34. Deci, E.L.; Olafsen, A. H.; Ryan, R.M., Self-Determination theory in work organizations: the state of science, Annu. Rev. Organ. Psychol. Organ. Behav., 2017, 4, 19-43.

35. Ryan, R. M., Control and information in the intrapersonal sphere: An extension of cognitive evaluation theory, Journal of Personality and Social Psychology, 1982, 43, 450-461.

36. Kozma R. B., 2008, Comparative Analysis of Policies for ICT in Education. In J. Voogt and G. Knezek (eds.), International Handbook of Information Technology in Primary and Secondary Education: Springer International Handbook of Information Technology in Primary and Secondary Education (vol 20). Boston, MA: Springer.

37. OECD, OECD Science, Technology and Industry Scoreboard 2017: The digital transformation, OECD Publishing: Paris, 2017, http://dx.doi.org/10.1787/9789264268821-en.

38. Wagner, D.; Day, B.; James, T.; Kozma, R. B.; Miller, J.; Unwin, T., Monitoring and evaluation of ICT in education projects. A Handbook for Developing Countries, InfoDev/World Bank: Washington DC, 2005.

39. Condie, R.; Munro, R., The impact of ICT in schools: A landscape review, University of Strathclyde: Strathclyde, 2007.

40. Sáinz, M.; López-Sáez, M., Gender differences in computer attitudes and the choice of technology-related occupations in a sample of secondary students in Spain, Computers E Education, 2010, 54, 578-587.

41. Tondeur, J.; Van de Velde, S.; Vermeersch, H.; Van Houtte, M., Gender Differences in the ICT Profile of University Students: A Quantitative Analysis. DiGeSt, Journal of Diversity and Gender Studies, 2016, 3, 1, 57-77.

42. Goode, J., Mind the gap: The digital dimension of college access, The Journal of Higher Education, 2010, 81, 583-618.

43. Bovée, C.; Voogt, J.; Meelissen, M., Computer attitudes of primary and secondary students in South Africa, Computers in Human Behavior, 2007, 23, 1762-1776.

44. Shapka, J. D.; Ferrari, M., Computer-related attitudes and actions of teacher candidates, Computers in Human Behavior, 2003, 19, 319-334.

45. Kay, R. H., Exploring gender differences in computer-related behaviour: past, present, and future. In Social information technology: connecting society and cultural issues, Chen, T. T., Chen, I., Eds.; Information Science Reference: Hershey, United States; 2008, pp. 12-30.

46. Cai, Z.; Fan, X.; Du, J., Gender and attitudes towards technology use: A meta-analysis, Computers E Education, $2017,105,1-13$.

47. Aguiar, M. V.; Cuesta, H., Importancia de trabajar las TIC en Educación Infantil a través de Métodos como las WebQuest, Revista de Medios y Educación, 2009, 34, 81-94.

48. Clares, J.; Gil, J., Recursos tecnológicos y metodologías de enseñanza en titulaciones del ámbito de las ciencias de la educación, Bordón, 2008, 60, 3, 21-33.

49. Carnoy, M., Las TIC en la enseñanza: posibilidades y retos, 2004, Retrieved from http://www.uoc.edu/inaugural04/dt/esp/carnoy1004.pdf

50. Preston, C.; Cox, M. J.; Cox, K. M. J., Teachers as Innovators in Learning: What motivates teachers to use ICT, Croydon: Mirandanet, 2000.

51. Edmunds, R.; Thorpe, M.; Conole, G., Student attitudes towards and use of ICT in course study, work and social activity: A technology acceptance model approach, British Journal of Educational Technology, 2012, 43, 1, 71-84.

52. Méndez, D., El aprendizaje cooperativo y la enseñanza tradicional en electricidad y magnetismo en secundaria, Enseñanza de las ciencias, 2013, No. extra, 2297-2302.

53. Méndez, D., Estudio de las motivaciones de los estudiantes de secundaria de Física y Química y la influencia de las metodologías de enseñanza en su interés, Educación XXI, 2015, 18, 2, 215-2355, doi: 10.5944/educXX1.14016.

54. Gokcearslan, S., Perspectives of students on acceptance of tablets and self-directed learning with technology, Contemporary educational technology, 2017, 8, 1, 40-55.

55. Sharples, M.; Taylor, J.; Vavoula, G., Towards a theory of mobile learning. In Mobile technology: The future of learning in your hands, van der Merwe, H., Brown, T., Eds.; mLearn: Cape Town, South Africa; 2005; p. 58.

56. Sharples, M.; Taylor, J.; Vavoula, G., A Theory of Learning for the Mobile Age. In The Sage Handbook of Elearning Research Sage, Andrews, R., Haythornthwaite, C., Eds.; London, United Kingdom, 2007; pp. 221-47.

57. Méndez, D.; Slisko, J., Software Socrative and Smartphones as Tools For Implementation of Basic Processes of Active Physics Learning in Classroom: An Initial Feasibility Study With Prospective Teachers, European Journal of Physics Education, 2013, 4, 2, $17-24$.

58. Méndez, D.; Hargis, J., The effect of the computers in the learning of formulation with secondary students, Journal of science education, 2014, 15, 1, 19-21.

59. Sanz, J. J., Ipad y motivación, Revista Caribeña de Ciencias Sociales, 2013, 10.

60. Mendez, D.; Sota, J., La influencia del uso del tablet en la motivación en ciencias de los alumnos de primaria, Enseñanza de las ciencias, 2017, 975-980. 
61. Mendez, D.; Mendez, M.; Anguita, J., Motivation of 14 Year-old Students using Tablets, compared to those using Textbooks and Workbooks, International Journal of Interactive Mobile Technologies, 2018, 12, 4, 86-96. https://doi.org/10.3991/ijim.v12i4.9203.

62. Dündar, H.; Ve Akçayır M., Implementing tablet PCs in schools: Students' attitudes and opinions, Computers in Human Behavior, 2014, 32, 40-46.

63. Huertas, A.; Pantoja, A., Efectos de un programa educativo basado en el uso de las TIC sobre el rendimiento académico y la motivación del alumnado en la asignatura de Tecnología de Educación Secundaria, Educación XX1, 2016, 19, 2, 229-250. Retrieved from https://www.redalyc.org/pdf/706/70645811009.pdf 